\section{Performance of Drainage Lysimeters for the Evaluation of Water Use by Asian Pears}

\author{
David J. Chalmers', Preston K. Andrews', Kevin M. Harris ${ }^{3}$, and \\ Ewen A. Cameron ${ }^{4}$ \\ Department of Horticultural Science, Massey University, Palmerston \\ North, New Zealand
}

Horst W. Caspari ${ }^{5}$

Institut für Obstbau und Gemüsebau, Universität Bonn, Bonn, Germany

Additional index words. Pyrus serotina, Japanese pear, Nashi, evapotranspiration

\begin{abstract}
The design of a type of drainage lysimeter, as tested with trees of Pyrus serotina Rehder var. culta Rehder 'Hosui' is described. All lysimeter operations and monitoring of irrigation and drainage volumes were managed by a "multi-tasking" controller/datalogger. It was possible to apply different irrigation levels to each of three sets of four random lysimeters. Evapotranspiration (ET) was calculated using a conservation of water equation, with differences between irrigation inputs and drainage outputs corrected for changes in soil-water content. ET ranged between 3.3 and 10.7 liters/tree per day in well-watered, noncropped trees in late Summer and Fall 1990. These rates correspond to ET of 0.13 to $0.43 \mathrm{liter}^{\cdot} \mathrm{cm}^{-2} \cdot \mathrm{day}^{-1}$ and 0.96 to 3.10 liters $\cdot \mathrm{m}^{-2} \cdot \mathrm{day}^{-1}$ on trunk cross-sectional area and canopy area bases, respectively. The correlation coefficient between ET and Class A pan evaporation was $>0.9$ during this period. Weekly crop coefficients for the well-watered trees averaged 0.52 when calculated on a canopy-area basis. When irrigation was withheld for 18 days, the crop coefficient declined to 0.38 . There were no differences in ET between trees growing in the two soil profiles, despite significant differences in soil water distribution.
\end{abstract}

A lysimeter is a container that isolates a soil environment from the surrounding soil, yet provides a surface that is representative of the adjacent land. Its purpose is to maintain a controlled soil-water or -nutrient environment for precise measurement of their use by crops and mobilization within soils. Lysimeters may be of either the weighing or drainage types. Weighing lysimeters are capable of accurately relating changes in weight to the evapotranspiration (ET) of a crop over

Received for publication 4 Apr. 1991. Accepted for publication 28 Oct. 1991. H/LA Paper no. 9101, 'College of Agriculture and Home 'Economics Research Center, Washington State Univ., Pullman. Supported by a grant from the University Grants Committee, New Zealand. Mention of trade names does not constitute a guaranty or warranty of the products by Massey Univ., nor does it imply endorsement over similar commercial products. The cost of publishing this paper was defrayed in part by the payment of page charges. Under postal regulations, this paper therefore must be hereby marked advertisement solely to indicate this fact.

Professor. Current address: Charles Sturt University-Riverina, P.O. Box 588, Wagga Wagga, NSW, Australia.

Postdoctoral Fellow. Current address: Dept. of Horticulture and Landscape Architecture, Washington State Univ., Pullman, WA 99164-6414. ${ }^{3}$ Senior Technical Officer.

${ }^{4}$ Lecturer, Dept. of Agricultural and Horticultural Systems Management.

Visiting Scientist, supported by a grant from Gottlieb Daimler- and Karl Benz-Foundation. Current address: Dept. of Horticultural Science, Massey Univ., Palmerston North, New Zealand. daily, or even hourly, intervals (Black et al., 1968; Van Bavel and Meyers, 1962). The precision of weighing lysimeters, however, strongly depends on the quality and design of the load cells used to measure these changes in weight. Maintaining the stability of load cells may pose problems with tree crops, especially in windy climates. Drainage lysimeters can avoid this difficulty by measuring irrigation and drainage volumes, with ET estimated via a conservation of water equation.

Asian (Nashi) pears are native to Japan and southern China (Kituchi, 1924). While small commercial plantings have existed in California since early in this century, and the Univ. of California at Davis has maintained clonal stocks, little research has been reported regarding the physiology of this highvalue tree fruit (Griggs and Iwakiri, 1982). Significant plantings of Asian pears have occurred in New Zealand in recent years (Wilton, 1987). There are no reports on wateruse requirements of this crop. The lysimeter facility, whose design and performance is described here, was constructed at Massey Univ., New Zealand, to study this aspect of Asian pear physiology.

In 1986, twelve lysimeters were sited within a 1.1-ha block of Asian pears that was planted in 1985-86. Each lysimeter container consisted of a steel cylinder $1 \mathrm{~m}$ in diameter and $1.2 \mathrm{~m}$ deep. The bottom $0.2 \mathrm{~m}$ was conical in shape, with polyethylene pipe connected to the outlet at the apex to transport drainage water. Each steel container was enclosed by a concrete sleeve situated so as to provide a $1.2-\mathrm{m}$ tree spacing within the row. Between- row spacing was $5 \mathrm{~m}$. The top lip of the steel containers was $\approx 0.1 \mathrm{~m}$ above the ground surface.

The bottom $0.2 \mathrm{~m}$ of each lysimeter was filled with sand filter. In eight randomly selected lysimeters, a "disturbed" B horizon of Manawatu fine sandy loam ("disturbed" bulk density $=1.44 \mathrm{~g} \cdot \mathrm{cm}^{-3}$ ) was packed in 0.1-m layers to within $0.05 \mathrm{~m}$ of the top of each lysimeter (B-horizon lysimeters). In the remaining lysimeters, a gravelly coarse sand $\mathrm{C}$ horizon was placed in the lower $0.4 \mathrm{~m}$ with the B horizon in the upper $0.6 \mathrm{~m}(\mathrm{~B} / \mathrm{C}$ horizon lysimeters). This sequence produced a textural interface that impeded water transport, yet was more freely draining below than the B horizon alone (Clothier et al., 1977a, 1977b). This type of soil structure is prevalent in this region of New Zealand and has been observed to restrict the root activity of maize and pasture grass to the horizons above the gravelly coarse sand (B.E. Clothier, 1990 personal communication). The cation exchange capacities, bulk densities, and particle densities of the undisturbed $\mathrm{B}$ and $\mathrm{C}$ horizons were 7 to 10 and $5.1 \mathrm{meq} \%, 1.28$ to 1.38 , and $1.37 \mathrm{~g} \cdot \mathrm{cm}^{-3}$, and 2.66 to 2.70 and $2.71 \mathrm{~g} \cdot \mathrm{cm}^{-3}$, respectively (A.S. Palmer, 1990 personal communication).

One tree of $P$. serotina 'Hosui', grafted on seedling rootstock, was planted in each of the lysimeters in Sept. 1987. The trees were trained onto a Tatura trellis (Chalmers et al., 1978). Only light pruning had been performed from planting through the 1990 growing season, with most training consisting of tying branches to the trellis wires.

The trees were irrigated and fertilized via a closed nutrient-feed system from two 9000liter tanks that were supplied by a deep well. The nutrient solution consisted of the following elements and concentrations (mg.liter $\left.{ }^{-1}\right)$ : $\mathrm{N}, 105 ; \mathrm{P}, 15.5 ; \mathrm{K}, 70.1 ; \mathrm{Ca}, 125 ; \mathrm{Mg}$, 48.6; S, 64.0; Fe, 3.0; Cl, 0.4; B, 0.25; $\mathrm{Mn}, 0.25 ; \mathrm{Zn}, 0.025 ; \mathrm{Cu}, 0.01$; and $\mathrm{Mo}$, 0.004 .

The nutrient solution was divided into three distribution pipes. The flow in each pipe was controlled by a solenoid, followed by a pressure regulator and flow meter (FM) (Picoflux EV Superjet, Andrae Leonberg, Leonberg, West Germany). Each of two solenoids distributed nutrient solution to four randomly selected B-horizon lysimeters. The third solenoid supplied nutrient solution to all four of the B/C-horizon lysimeters. The nutrient solution was applied to the surface of the soil in each lysimeter through eight pressurecompensated trickle emitters (Netafim, Israel), each rated for 2 liters $\cdot h^{-1}$ flow rate. The emitters were equidistant from each other, in a circle $0.3 \mathrm{~m}$ from the tree trunk. To reduce soil heating, evaporation from the soil surface, and the influx of precipitation, each lysimeter was covered with a reflective, opaque, rigid-plastic cover. Since evaporation from the surface of the soil is directly related to net radiation, it was assumed that this contribution to ET would be minimal beneath the canopy, particularly under the humid conditions in New Zealand (Jensen et al., 1989). 
Table 1. Class A pan evaporation, evapotranspiration, and crop coefficients (per canopy area) of Pyrus serotina Rehder var. culta Rehder 'Hosui' trees in 12 drainage lysimeters under excess irrigation and during a soil drying period in late Summer and Fall 1990.

\begin{tabular}{|c|c|c|c|c|}
\hline \multirow[b]{2}{*}{ Dates } & \multirow[b]{2}{*}{$\begin{array}{c}E_{\text {pan }^{2}} \\
\text { (mm·day } \\
-1)\end{array}$} & \multicolumn{2}{|c|}{ Mean evapotranspiration } & \multirow[b]{2}{*}{$\begin{array}{l}\text { Crop coefficient } \\
\text { (canopy area) }\end{array}$} \\
\hline & & $\begin{array}{c}\mathrm{TCA}^{\mathrm{y}} \\
\left(\text { liter } \mathrm{cm}^{-2} \cdot \mathrm{day}^{-1}\right)\end{array}$ & $\begin{array}{c}\text { Canopy area } \\
\left(\text { liter } \cdot m^{-2} \cdot \text { day }^{-1}\right)\end{array}$ & \\
\hline 14-20 Feb. & 5.07 & 0.43 & 3.10 & 0.61 \\
\hline 8-14 Mar. & 2.06 & 0.13 & 0.96 & 0.46 \\
\hline 15-22 Mar. & 4.50 & 0.24 & 2.03 & 0.45 \\
\hline 23-29 Mar. & 3.06 & 0.22 & 1.78 & 0.58 \\
\hline Significance & & $* * *$ & $* * *$ & \\
\hline \multicolumn{5}{|c|}{31 Mar.-20 Apr.w } \\
\hline 0-9 days & 2.69 & 0.13 & 1.08 & 0.40 \\
\hline $9-18$ days & 2.21 & 0.09 & 0.79 & 0.36 \\
\hline Significance & & NS & $*$ & \\
\hline
\end{tabular}

${ }^{2}$ Mean daily Class A pan evaporation.

${ }^{y}$ TCA, trunk cross-sectional area. Weekly median TCA calculated from trunk circumference measurements made $10 \mathrm{~cm}$ acropetal to the graft union, with the assumption that the cross-sectional outlines were circular.

${ }^{x}$ Canopy area calculated as the sum of four rectangles, two on each side of the Tatura trellis.

"18-day soil-drying period following the termination of irrigation. Day 0 indicates when drainage ceased.

Ns,*,***Nonsignificant or significant at $P=0.05$ or 0.001 , respectively.

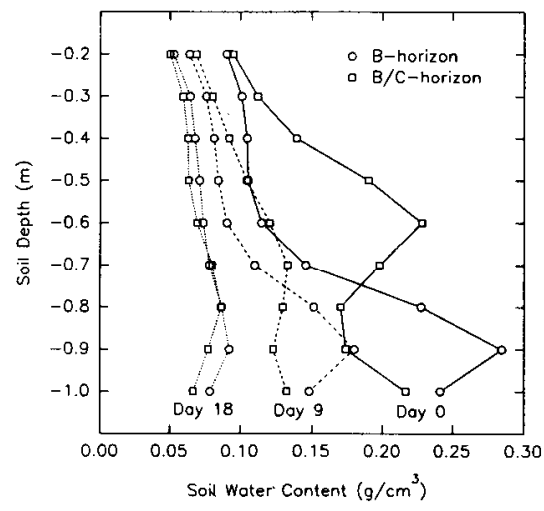

Fig. 1. Soil water-content profiles, measured with a neutron hydroprobe, during 18 days of drying after drainage ceased of four of each of the Band B/C-horizon lysimeters in which Pyrus serotina Rehder var. culta Rehder 'Hosui' trees were planted.

The drainage from each lysimeter was routed through polyethylene pipe to tippingbucket gauges (Pronamic, Them, Denmark) located within a subterranean control room. The drainage gauges (DGs) registered a pulse for every $5 \mathrm{ml}$ of drainage volume. Each 5 $\mathrm{ml}$ of drainage solution passing through a gauge was emptied into a reservoir that was pumped to the surface and discarded away from the site.

The lysimeter facility was automatically operated by a multi-tasking controller/datalogger (Wormald 1830, Christchurch, New Zealand) using Control-Basic language (version 1.00). Hourly accumulated irrigation and drainage volumes were stored in arrays dimensioned daily within the program. Each week, data from the arrays were transferred to diskette on a MS-DOS personal computer that acted as screen and keyboard for the controller/datalogger.

Irrigation volumes for individual lysimeters were determined by dividing weekly FM volumes by four lysimeters per FM, corrected by previously determined calibration factors that were functions of emitter accu- racy. Calibration factors were derived for each lysimeter from comparisons between datalogged FM values and actual irrigation volumes emitted. Drainage volumes for each DG were accurately measured within $\pm 5 \%$ and were uncorrected.

ET was determined indirectly, using a simplified, conservation of water equation (Sharma, 1985): ET $=\mathrm{I}-\Delta \mathrm{W}-\mathrm{D}$ where I is irrigation, $\Delta \mathrm{W}$ is the change in the soil water content, and $\mathrm{D}$ is drainage out of the defined volume. The $\Delta \mathrm{W}$ was calculated for each lysimeter from weekly neutron hydroprobe (Model 503DR, CPN Corp., Martinez, Calif.) measurements made $0.5 \mathrm{~m}$ from the trunk of each tree at $0.2-\mathrm{m}$ intervals, from 0.2 to $1.0 \mathrm{~m}$ beneath the soil surface. The hydroprobe was calibrated by the method of Campbell and Campbell (1982). Water contents in millimeters were calculated for the depths 0 to $0.3,0.3$ to $0.5,0.5$ to $0.7,0.7$ to 0.9 , and 0.9 to $1.0 \mathrm{~m}$. Soil-water content was converted to liters by multiplying total soil water content by $0.785 \mathrm{~m}^{2} /$ lysimeter, since $1 \mathrm{~mm}=1$ liter $\cdot \mathrm{m}^{-2}$.

Trunk cross-sectional areas (TCAs) were calculated from trunk circumference measurements made $10 \mathrm{~cm}$ above the graft unions. The cross-sectional outlines of the trunks were assumed to be circular. Mean TCA increased from 24.7 to $28.5 \mathrm{~cm}^{2}$ during the measurement period, with SE of the means (SEM) of 1.7 to $1.9 \mathrm{~cm}^{2}$. The canopy area of each tree was calculated by summing the area of four rectangles, two on either side of the Tatura trellis, that best represented the canopy outline.

Pan evaporation $\left(\mathrm{E}_{\mathrm{pan}}\right)$ data were obtained from a Class A evaporation pan located $\approx 1$ $\mathrm{km}$ from the lysimeter facility.

The trees were irrigated to excess from Nov. 1989-29 Mar. 1990, so that all lysimeters were at "field capacity." Irrigation was applied during three periods each day. Soil moisture tensions, measured with in situ tensiometers (Loktronic, Irrigation Technology and Management, Wanganui, New Zealand), were 4 to $8 \mathrm{kPa}$ and 9 to $14 \mathrm{kPa}$ at
30- and 90-cm depths, respectively. Irrigation was terminated on 29 Mar. The trees were not cropped during the 1989-90 growing season.

$\mathrm{E}_{\text {pan }}$ and ET varied considerably during 4 weeks in late Summer and Fall 1990 (Table 1). Mean weekly ET per tree varied from 3.3 to 10.7 liters/tree per day during these weeks. Substantial daily fluctuations in $\mathrm{E}_{\mathrm{pan}}$ and low maximum daily $\mathrm{E}_{\mathrm{pan}}$ values are typical in New Zealand. The maximum daily $\mathrm{E}_{\mathrm{pan}}$ during the period Nov. 1989-Mar. 1990 was $8 \mathrm{~mm} \cdot$ day $^{-1}$, with an average of only 5 $\mathrm{mm} \cdot \mathrm{day}^{-1}$.

Soil-water contents throughout the lysimeter soil profiles were determined following the termination of irrigation on 29 Mar. by measuring the water content at $0.1-\mathrm{m}$ intervals from 0.2 to $1.0 \mathrm{~m}$ below the soil surface, as described previously. Four of each of the B- and B/C-horizon lysimeters were measured. Measurements were begun when all drainage had ceased and were made 1,2 , $3,4,6,9$, and 18 days afterward. The final measurements were made on $20 \mathrm{Apr}$. When drainage had ceased (Day 0), the B-horizon lysimeters contained 112.4 liters/lysimeter and the B/C-horizon lysimeters contained 122.0 liters/lysimeter. These soil-water contents were not significantly different $(P=$ 0.064 by ANOVA).

The B/C-horizon interface in the lysimeters resulted in a soil-water content curve (Fig. 1) similar to that found in an undisturbed Manawatu fine sandy loam profile (Clothier et al., 1977a, 1977b). The differences in water distribution between the B/Cand $\mathrm{B}$-horizon lysimeters is the result of water perched above the B/C-horizon interface. The $\mathrm{C}$ horizon of the $\mathrm{B} / \mathrm{C}$-horizon lysimeters, however, contained sufficient water to support root growth under excess irrigation. Indeed, roots were observed in the $\mathrm{C}$ horizon when examined through a plexiglass tube with a root endoscope (Ultrafine Technology, London). Nine days following the cessation of drainage, the B/C-horizon interface showed little evidence of water accumulation (Fig. 1), indicating water uptake by roots in this region of the profile. After 18 days, there was little difference in the soil-water contents of either B- or B/C-horizon lysimeters, indicating that trees in either the $\mathrm{B}-$ or $\mathrm{B} / \mathrm{C}$ horizon lysimeters were using water at about the same rate.

During the soil-drying period, the ET of trees in the $\mathrm{B}$ - and $\mathrm{B} / \mathrm{C}$-horizon lysimeters was not significantly different as determined by depletion in soil-water storage. During the first 9 days of drying, the depletions were 33.2 liters/lysimeter $(\mathrm{SEM}=8.0)$ and 41.7 liters/lysimeter $(\mathrm{SEM}=8.4)$ for the B- and B/C-horizon lysimeters, respectively, while during the second 9 days they were 23.7 liters/lysimeter $(\mathrm{SEM}=2.0)$ and 28.6 liters/ lysimeter $(\mathrm{SEM}=1.6)$. These depletions resulted in ET of 4.2 and 2.9 liters/tree per day for the 0 to 9 and 9 to 18 day intervals, respectively. During days O-9, ET was strongly correlated with TCA $(R=0.93$, $P<0.01)$, whereas from days 9-18 there was no significant correlation $(\mathrm{R}=0.18)$. 
Since TCA was significantly correlated with canopy area $(R=0.88, P<0.001)$, these data suggested that trees with greater evaporative capacity transpired at a higher rate during the first 9 days relative to trees with less evaporative capacity, than during the second 9 days. These differences in ET were independent of the soil profiles in which the trees were growing. ET rates during the two soil-drying intervals were similar to those under excess irrigation (Table 1). Correlation coefficients between ET and $\mathrm{E}_{\mathrm{pan}}$ during the four excess-irrigation intervals and the two soil-drying intervals were $0.91(P<0.05)$ and $0.95(P<0.01)$ on TCA and canopy area bases, respectively. Worthington et al. (1984) also found a strong correlation between $\mathrm{E}_{\mathrm{pan}}$ and ET $(R=0.88, \mathrm{n}=18)$, based on weekly averages.

Methods for determining crop coefficients $\left(\mathrm{k}_{\mathrm{c}}\right.$ from pan evaporation and water-use data vary (Elfving, 1982). The principal difficulty lies in defining the actual size of the transpiring plant canopy. Crop coefficents have been reported on per canopy area, per planting area, and per shaded area (Elfving, 1982). When $\mathrm{k}_{\mathrm{c}}$ values were calculated on the basis of the canopy area of the pear trees, they averaged $0.52(\mathrm{SEM}=0.04)$ during the well-watered period, decreasing to 0.38 $(\mathrm{SEM}=0.02)$ during soil drying (Table 1). The values fluctuated during the well-watered period. Although there was no correlation between $E_{\text {pan }}$ and $k_{c}$, lower values of $k_{c}$ were associated with periods of lower $\mathrm{E}_{\mathrm{pan}}$. Worthington et al. (1984) reported $\mathrm{k}_{\mathrm{c}}$ to be 0.4 to 1.0 for peaches [Prunus persica (L.) Batsch.], on a canopy-area basis. They found increased variability, and an overall decline, in $\mathrm{k}_{\mathrm{c}}$ during the fall. Declining $\mathrm{k}_{\mathrm{c}}$ during fall may be related to reduced sensitivity of stomata as leaves begin to senescence (Faust, 1989) or to water stress, which may have been a factor in this instance.

Doorenbos and Pruitt (1977) recommended employing a pan coefficient $(\mathrm{k}$, ) to calculate a reference crop ET (ET,) before calculating the ET of the crop in question. Under typical weather conditions in this region of New Zealand, $\mathrm{k}_{\mathrm{p}}$ would be 0.7 to 0.8 (Doorenbos and Pruitt, 1977). Values of $\mathrm{k}_{\mathrm{c}}$ are then multiplied by ET, to estimate crop ET. These authors reported $\mathrm{k}_{\mathrm{c}}$ values of 0.95 to 1.0 and 1.05 to 1.1 for European pears (Pyrus communis L.) and apples (Malus domestica Borkh.), respectively. Multiplying these $\mathrm{k}_{\mathrm{p}}$ and $\mathrm{k}_{\mathrm{c}}$ values results in an overall $\mathrm{k}_{\mathrm{c}}$ of 0.7 to 0.9 for apples and pears. This range of overall $\mathrm{k}_{\mathrm{c}}$ for European pears and apples is slightly greater than those measured for Asian pears growing in lysimeters under New Zealand conditions.

Diurnal drainage patterns corresponded to expected diurnal ET (data not shown), with drainage rates decreasing between 0900 and 1000 HR and increasing again between 1800 and 2000 HR. This pattern might suggest the possibility of daily ET determinations rather than mean daily ET calculated on a weekly basis, as reported here. Sharma (1985) warned that measurement of changes in soil-water content by the neutron moderation technique is generally inaccurate for periods less than a week unless evapotranspiration rates are very high. Indeed, even Worthington et al. (1984) presented the ET of peaches growing in weighing lysimeters on a weekly basis, even though weighing lysimeters have been reported to provide sensitive hourly ET estimates (Sharma, 1985). McFarland et al. (1983) found, however, that wind loading on the trees in these lysimeters made hourly measurements of ET invalid. Based on these conclusions and the performance of this lysimeter facility, drainage lysimeters appear to be a viable alternative to weighing lysimeters for monitoring the ET of trees in windy climates.

\section{Literature Cited}

Black, T.A., G.W. Thurtell, and C.B. Tanner. 1968. Hydraulic load-cell construction, calibration and tests. Soil Sci. Soc. Amer. Proc. 32:623-629.
Campbell, G.S. and M.D. Campbell. 1982. Irrigation scheduling using soil moisture measurements: Theory and practice. Adv. Irr. 1:25-42.

Chalmers, D., B. van den Ende, and L. van Heek. 1978. Productivity and mechanization of the Tatura trellis orchard. HortScience 13:517-521.

Clothier, B.E., D.R. Scotter, and J.P. Kerr. 1977a. Water retention in soil underlain by a coursetextured layer: Theory and a field application. Soil Sci. 123:392-399.

Clothier, B.E., D.R. Scatter, and J.P. Kerr. 1977b. Drainage flux in permeable soil underlain by a coarse-textured layer. Soil Sci. Soc. Amer. J. 41:671-676.

Doorenbos, J. and W.O. Pruitt. 1977. Guidelines for predicting crop water requirements. Food and Agr. Org. (FAO) Irrigation and Drainage Paper 24. FAO, United Nations, Rome.

Elfving, D.C. 1982. Crop response to trickle irrigation. Hort. Rev. 4:1-48.

Faust, M. 1989. Physiology of temperature zone fruit trees, p. 152. Wiley, New York.

Griggs, W.H. and B.T. Iwakiri. 1982. Asian pears in California. o. 13-23. In: T. van der Zwet and N.F. Childers (eds.). The pear. Horticultural Publ., Gainesville, Fla.

Jensen. M.E.. R.D. Burman, and R.G. Allen (eds:). 1989. Evapotranspiration and irrigation water requirements. Amer. Soc. Civil Eng., New York. p.50-53.

Kituchi, A. 1924. On the origin of Japanese pears and the inheritance of skin colour of their fruits. Jpn. J. Genet. 3:1-21.

McFarland, M.J., J.W. Worthington, and J.S. Newman. 1983. Design, installation and operation of a twin weighing lysimeter for fruit trees. Trans. Amer. Soc. Agr. Eng. 26:1717-1721.

Sharma, M.L. 1985. Estimating evapotranspiration. Adv. Irr. 3:213-281.

Van Bavel, C.H.M. and L.E. Meyers. 1962. An automatic weighing lysimeter. Agr. Eng. 43:580588.

Wilton, W.J.W. 1987. Nashi-market prospects. Proc. Ruakura Hort. Conf., Nashi. Min. Agr. and Fisheries, Hamilton, New Zealand. p. 2528.

Worthington, J.W., M.J. McFarland, and P. Rodrigue. 1984. Water requirements of peach as recorded by weighing lysimeters. HortScience 19:90-91. 